\title{
Sympathy for Cecil: gender, trophy hunting, and the western environmental imaginary
}

\author{
Eric S. Godoy ${ }^{1}$ \\ Illinois State University, USA
}

\begin{abstract}
This article draws from political ecology and ecofeminism to examine sympathy, expressed by record-breaking donations from North Americans, for the death of Cecil the Lion. The overlapping normative critique offered by these two perspectives together demonstrates how sympathy is disclosive of power relations. Sympathy reveals, relies upon, and reinforces different forms of gender, racial, and neocolonial domination; especially when western sympathy remains ignorant of the power relations, including their politics and histories, that shape attitudes toward non-human animals and grant them status as members of the (western) moral community. Keywords: sympathy, ecofeminism, trophy hunting, wildlife conservation, Cecil the Lion
\end{abstract}

\section{Résumé}

Cet article s'inspire de l'écologie politique et de l'écoféminisme pour examiner la sympathie, exprimée par des dons record de Nord-Américains, pour la mort de Cecil le Lion. La critique normative qui se chevauchent offerte par ces deux perspectives montre ensemble comment la sympathie révèle les relations de pouvoir. La sympathie révèle, s'appuie sur et renforce différentes formes de domination sexiste, raciale et néocoloniale; en particulier lorsque la sympathie occidentale reste ignorante des relations de pouvoir, y compris leur politique et leur histoire, qui façonnent les attitudes envers les animaux non humains et leur accordent le statut de membres de la communauté morale (occidentale).

Mots-clés: sympathie, écoféminisme, chasse aux trophées, conservation de la faune, Cecil le Lion

\section{Resumen}

Este artículo se basa en la ecología política y el ecofeminismo para examinar la simpatía, expresada por las donaciones récord de los norteamericanos, por la muerte de Cecil el León. La crítica normativa superpuesta que ofrecen estas dos perspectivas juntas demuestra cómo la simpatía revela las relaciones de poder. La simpatía revela, se basa y refuerza las diferentes formas de dominación de género, racial y neocolonial. Especialmente cuando la simpatía occidental sigue ignorando las relaciones de poder, incluidas sus políticas e historias, que dan forma a las actitudes hacia los animales no humanos y les otorgan el estatus de miembros de la comunidad moral (occidental).

Palabras clave: simpatía, ecofeminismo, caza de trofeos, conservación de la vida silvestre, Cecil el León

\section{The death of a lion}

In the summer of 2015, Walter J. Palmer, a dentist from Minnesota, made a trip to the Hwange District in northwestern Zimbabwe. He hired professional hunter Theo Bronkhorst for US\$50,000 to help him hunt and

\footnotetext{
${ }^{1}$ Dr. Eric S. Godoy, Assistant Professor, Department of Philosophy, Illinois State University, Normal, IL, USA. Email: esgodoy "at" ilstu.edu. I am grateful for the many comments from referees, colleagues, students, and commentators that helped improve this article, and for support from Illinois State University to develop and present this research.
} 
kill a lion (Panthera leo) (Loveridge 2018: 211). ${ }^{2}$ They drove to a legal hunting ground on the edge of the Hwange National Park. Lion-hunting isn't allowed in the park; however, the area immediately surrounding the park is part of their natural range. A number of "safari lodges" are located nearby, though not all of them are for tourists wishing to hunt. Many take sightseeing excursions into the park and shoot only photos. Palmer and Bronkhorst used bait to attract a male lion, a common practice when hunting them, to Antoinette Farm. At approximately 10pm, on July 1, Palmer shot the lion with a bow and arrow wounding him. About eleven hours later, they managed to track down the bleeding animal and kill him (Loveridge 2018; Macdonald, Jacobsen, et al. 2016).

The lion was under study by Oxford University's Wildlife Conservation Research Unit (WildCRU) and wore a GPS tracking collar. ${ }^{3}$ The hunting party destroyed the collar after collecting the "trophy" (the head and skin). Hunters often destroy tracking collars after illegal hunts, but it's not illegal to kill a lion wearing one; in fact, the collars are extremely difficult to see, especially on male lions with full manes and under the dim lighting condition in which lions are often hunted. Most likely, Bronkhorst or Honest Ndlovu, the owner of the farm where Cecil was shot, destroyed the collar because they didn't secure the proper permits for hunting on Antoinette Farm. Had the permits been acquired there would have been nothing illegal about this event. Professional hunters are often hired by tourists to conduct these hunts; in fact, Bronkhorst founded Bushman Safaris, which specializes in an all-inclusive, archery-only experience.

Yet the death of this lion sparked a firestorm of media attention. The lion was described as something of a local celebrity, and nicknamed Cecil (a name, as many locals noticed, that resembles Cecil John Rhodes, the British founder of the white settler state Rhodesia, now Zimbabwe) (Jenkins 2015). Cecil the Lion was fondly known by guides in the Hwange National Park as a tourist attraction. He was anything but camera shy, so tourists often captured pictures of him (Figure 1). According to one study, editorial media covering Cecil peaked at nearly 12 thousand mentions just two weeks after Palmer shot him (Macdonald and Jacobsen et al. 2016: 5). The number of mentions on Facebook, Twitter, and YouTube combined was even larger at over 90 thousand worldwide, but primarily came from North America (Macdonald and Jacobsen et al. 2016: 6). Jimmy Kimmel, host of a late-night American talk show, choked up on air when reporting on Cecil's death. ${ }^{4}$ His plea for viewers to donate to WildCRU generated 4.4 million visitors that reportedly crashed Oxford's website. Within three months the group netted US\$1.06 million in donations (Macdonald and Jacobsen et al. 2016: 10).

WildCRU conducted a study attempting to understand the immense response to Cecil. They called it "the largest reaction in the history of wildlife conservation" (Macdonald and Jacobsen et al. 2016: 2). ${ }^{5}$ They even held a 4-day Cecil Summit, calling together a number of minds to think carefully over what such an event meant for the future of lion conservation (as well as the fundraising that powers it) (WildCRU n.d.). Curiously, the killing of other "celebrity animals", such as Ustad the Tiger and Legolas the Cheetah, didn't attract nearly the same amount of attention. ${ }^{6}$ Neither did Palmer's prior conviction of a felony charge for killing a black bear in an unauthorized area of Wisconsin, where his bribery attempt resulted in a fine of nearly US\$3,000 and a year of probation (Loveridge 2018: 212); however, these facts were quickly exposed by journalists. ${ }^{7}$

\footnotetext{
2 The media often reported conflicting details regarding these events. I cite published studies by groups and people who were close to the lions, especially Macdonald, Jacobsen, et al. (2016), Loveridge (2018), and Somerville (2016, 2020) whenever possible. However, I say more about the problems with relying on this narrative below.

${ }^{3}$ According to WildCRU, the purpose of the study was both lion conservation and "advancing the well-being of human communities living alongside them" (Macdonald and Jacobsen et al. 2016: 2).

${ }^{4}$ https://www.youtube.com/watch?v=saHGvxFAhE0 [accessed 27 July, 2020]

${ }^{5}$ Other notable academic and policy outcomes inspired by Cecil include a conference called "Cecil Summit" (WildCRU n.d.), the CECIL Act to limit the transportation of endangered animals-turned-trophies, and the aforementioned report and book. There was also a children's storybook (Hatkoff, Hatkoff and Hatkoff 2016). An image of Cecil was projected on the side of the Empire State Building in the month following his death (Loveridge 2018: 217).

${ }^{6}$ Harambe, the gorilla who grabbed a boy who fell into its cage at the Cincinnati Zoo, was killed on May 28, 2016, not even a year after Cecil. Although this sparked discussion and controversy, it did not see the same type of reaction or amount of coverage. I discuss this event further below.

${ }^{7}$ Palmer did not face charges for his crime, though both Bronkhorst and Ndlovu did. Ndlovu faced a US\$400 fine or a year in jail. He was able to post a US\$200 bail after being arrested (Miller 2015).
} 
The main finding of WildCRU's study was that the Cecil story spread because it elicited anger, especially over the fact that Palmer's intention was to collect a trophy (Macdonald and Jacobsen et al. 2016: 8-9). However, trophy hunting is neither illegal nor uncommon. Between 1999 and Cecil's death, 45 collared male lions were shot, 15 of which were shot on Antoinette Farm (Loveridge 2018: 202-203). ${ }^{8}$ Numerous articles were shared alongside the Cecil coverage showing the link between wildlife conservation and revenue brought in from trophy hunting. The WildCRU study found that popular opinion sides with Kant over Mill (principle over consequence) (Macdonald and Jacobsen et al. 2016: 9); that is, many believe it's wrong to kill an animal to collect a trophy even if the revenue from trophy hunts saves more animals (Macdonald and Jacobsen et al. 2016). However, this still doesn't explain why Cecil sparked such an uncharacteristic amount of controversy.

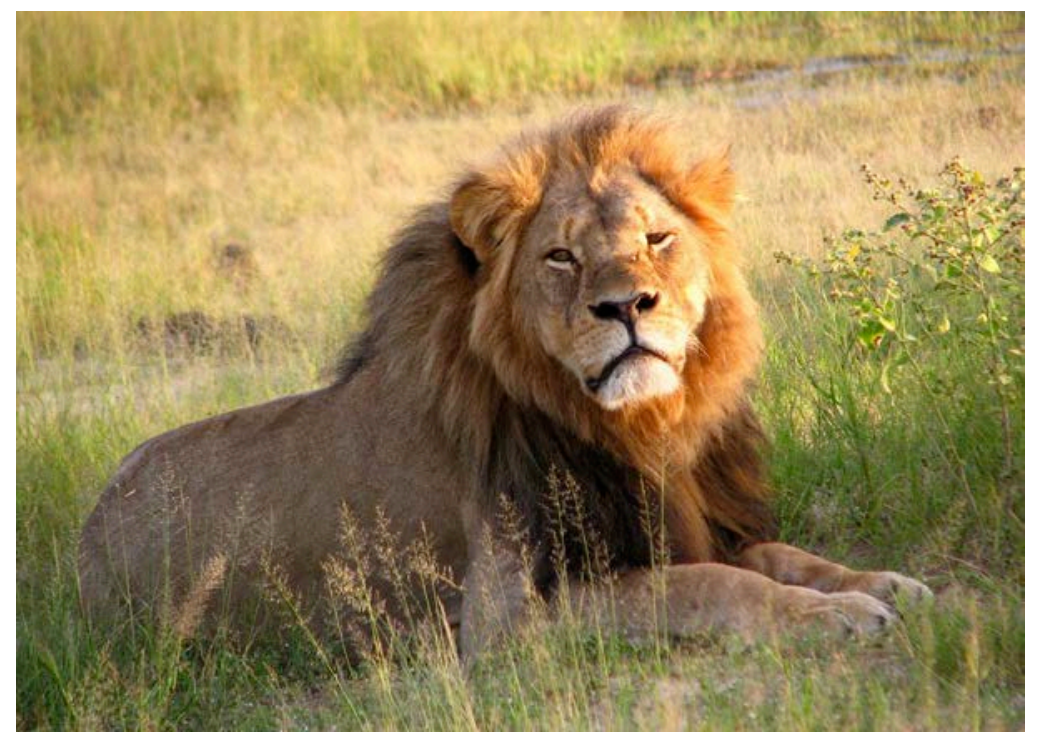

Figure 1: Cecil the lion, 2010. Source: By Daughter\#3 - Cecil, CC BY-SA 2.0, https://commons. wikimedia.org/w/index.php?curid=42030099

In this article, I reject the simple answer that anger was the cause of donations. As animal ethicists have noted, morally salient attitudes toward animals "do not float free, but are situated or embedded within networks of beliefs and practices" (Cooper 2015: 22). ${ }^{9}$ A more critical answer then will look to these networks of beliefs and practices to understand how the narrative surrounding Cecil's death was capable of inciting anger, a reaction that was not elicited by the similar deaths of many other lions. A political ecology of sympathy can help identify how emotions of the privileged are activated, drowning out the concern of others, to bolster conservation efforts worldwide (Mitchell 2017). The answer to why Cecil was able to activate these emotions is complicated and exceeds the scope of any one disciplinary approach. In what follows I draw from both ecofeminism and political ecology, which together better capture how western sympathy for Cecil reveals, relies upon, and reinforces different forms of gender, racial, and neocolonial power relations. Both fields are themselves multidisciplinary and concerned with normative critique. By engaging with each other, they offer a more thorough account of how sympathy for Cecil mobilized so much money, and who benefits from such sympathy.

\footnotetext{
${ }^{8}$ Loveridge (2018) offers a few more interesting numbers: in any given year, male lions have a $26-50 \%$ survival rate; the majority of those who do not survive are killed by hunters; and in 2002, permits to hunt 129 lions around Hwange were legally allocated (91).

${ }^{9}$ Cooper is here recounting and elaborating on the well-known work of animal ethicist Mary Midgley.
} 
In section 2, I draw from ecofeminism to analyze the highly gendered imaginary through which western donors view lions. Few in the west encounter lions outside of zoos or nature documentaries. I consider how the networks of beliefs and practices that shape the way many Americans perceive trophy hunting are saturated with gender norms. I focus on the Jimmy Kimmel Live monologue which immediately preceded the highest peak of editorial, social media, and donation activity. Using the concept of the "absent referent" (C.J. Adams 2000) I argue that Kimmel compared Palmer's trophy hunting to an act of sexual violence, which instigated further anger and sympathetic donations. In section 3, I continue this analysis by examining the origin of norms surrounding American sports hunting, which were established in part to define and secure power for western, white masculinity. Ecofeminists have long highlighted a problematic dualism in western thought that reinforces hierarchical power relations by associating the feminine and non-white with the bestial and the natural. The western environmental imaginary is suffused with these hierarchies and norms. They help define who can hunt and why, and in turn what violations of these norms warrant anger. I discuss the development of these attitudes in the linked histories of conservation and colonialism. In section 4, I turn to political ecology to ask who benefits from western sympathy. There is a complicated history in many formerly colonized places where lions roam, including Zimbabwe, regarding the use of wildlife as a renewable resource. I examine how elites shuffled rights to benefit from wildlife among themselves while displacing the burdens of large predators on the already marginalized. Tracing power relations between people here reveals how the western imaginary mobilizes sympathy as a force of domination and environmental injustice by presuming that the burden to preserve global wildlife falls on appropriately sympathetic westerners. I conclude with the claim that western sympathy can fail to benefit either lions or the people whose lives intersect with them. Instead, it often reinforces sexual, racial, and colonial power relations. An ecofeminist analysis and a political ecology of sympathy can together better expose these power relations and help critique them.

\section{Metaphors of sexual violence}

First, it's important to note that my analysis is centered on western sympathy since this is where most of the donations and sympathetic reactions came from. The story was only later picked up by Zimbabwe news outlets. There, many were shocked to learn that they even had a world-famous lion. In this section, I argue that understanding western sympathy for Cecil must account for the role that gender and race play in the Cecil narrative propagated by the media. Importantly, many North Americans do not regularly encounter lions outside of zoos or nature documentaries - two venues that disguise the conflict of interest that exists between such dangerous predator animals and the people who are likely to encounter them. It is important then to consider how the western imaginary grants a gendered and racialized access for both lions and other non-human animals to the western moral community. Concepts from ecofeminist writing help elucidate this access.

Recall that many Americans heard about Cecil from Kimmel's talk show, which immediately preceded the narrative's viral peak. In his monologue, Kimmel rehashed many details of Cecil's death before telling a series of jokes chastising Palmer. Emotion interjects itself into Kimmel's monologue for less than 5 seconds a quivering voice, a few nervous glances off camera - but the intensity of those 5 seconds is enhanced by gender. The spectacle of a man losing control of his emotions, even briefly as Kimmel did, surely contributed to the spread of his plea for donations. However, ecofeminist Carol Adams' concept of the absent referent (C. J. Adams 2000: 52ff) is especially helpful in unpacking the gendered metaphors on which Kimmel's jokes rely. These metaphors help reveal the problematic lens through which many Americans mischaracterize wildlife conflict and how their sympathy can easily be directed by playing into these gendered assumptions.

Ecofeminism "sees a connection between the exploitation and degradation of the natural world and the subordination and oppression of women" (Mellor 1998: 10). It is worth noting that, since its inception in the mid-1970s, the label "ecofeminism" has been applied to a wide body of theoretical positions, many criticized for their essentialism and other exclusionary assumptions about the identity of their subjects. However, ecofeminism's history is far from monolithic. Recently, scholars have begun reclaiming the value of the field's intersectional approach. They note voices within the field that were critical of many of its more problematic ideas all along, especially its essentialist leanings (Kings 2017; Mallory 2018; Mellor 1998). For Adams, the link between women and nature is not essential, but linguistic. It is found in the metaphors we use to describe 
violence against non-human animals and women. In English, although not exclusively so, a pig is distinguished from "pork" or "bacon", or a cow from "beef" or "hamburger." Animals are the absent referent in meat eating. Adams claims that violence against non-human animals and women are linked through this same structure of the absent referent:

Just as dead bodies are absent from our language about meat, in descriptions of cultural violence women are also often the absent referent. Rape, in particular, carries such potent imagery that the term is transferred from the literal experience of women and applied metaphorically to other instances of violent devastation, such as the "rape" of the earth in ecological writings of the early 1970s. The experience of women thus becomes a vehicle for describing other oppressions. Women, upon whose bodies actual rape is most often committed, become the absent referent when the language of sexual violence is used metaphorically. These terms recall women's experiences but not women. (C.J. Adams 2000: 53-54)

In other words, violence against nature is often described in terms that recall violence against women; although the reference to women is implicit, they explicitly remain absent. With the concept of the absent referent in mind, let's turn to Kimmel's markedly sexual jokes.

In one joke's setup, Kimmel asks of Palmer: "Is it that difficult for you to get an erection that you need to kill things that are stronger than you?" In the punchline, Kimmel suggests that taking an erectile disfunction medicine is a better choice for Palmer if he wishes to avoid becoming "the most hated man in America who never advertised Jell-O pudding on television" (Jimmy Kimmel Live 2015a). Importantly, the joke ends by comparing Palmer to African American comedian Bill Cosby. American audiences will recognize Cosby as a former spokesperson for Jell-O pudding. He appeared in product commercials for about 25 years. He was later accused by more than fifty women of sexual violence in a pattern of attacks taking place over several decades. In 2018, he was convicted of three counts of aggravated sexual assault and sentenced to serve a prison term of 3-10 years (Pearce 2018).

Invoking Cosby implies that Palmer's hunt was analogous to an act of sexual violence against Cecil. The structure of Kimmel's jokes relies on the audience to make a connection between violence against nature and a sexual assault, a connection in which women are the absent referent. Thus, this comparison elevates Palmer's hunt from just another violent act against non-human nature to a sexual transgression against a beloved, "local favorite" animal. Reporters included more details fitting this trope in their stories: the false reports that Cecil was lured out of his safety zone (many lions are baited and hunted alongside the park and this is a reliable source of income for landholders in the area) and ambushed at night (lions feed at night and this is when they are hunted); that Palmer is a serial offender since he was quickly revealed to be a frequent trophy hunter; and that he settled with a former dental assistant who accused him of sexual harassment (Loveridge 2018: 225). The many news stories, editorials, and social media shares combined false or exaggerated combinations of these details that made the event seem especially egregious: that hunting collared lions is illegal (it's not), that Cecil suffered for as long as 40 hours (it was about 11 hours), and that Cecil was beheaded (this is a normal practice in trophy hunting) (Loveridge 2018: 228). These details fit a familiar narrative of the sexual predator and allow for sympathy for the lion, a dangerous carnivore, when portrayed as a victim of a sexualized crime.

Importantly, these jokes only land for their intended audience if hunting can be understood as a metaphor for sexual performance, as a demonstration of potency. Hunting today is often discussed in gendered and even sexualized terms. One study sampled magazines from an 11-year period in Traditional Bowhunter magazine. It revealed a variety of "striking parallels between references to the (hetero)sexualization of non-human animals, women and weapons - as if the three were interchangeable sexual bodies" (Kalof, Fitzgerald and Baralt 2004: 241). For instance, killing is referred to as "scoring", death as "climax", turkeys as "redheads", and so on. The authors refer to this as hetero-sexualization since the "[s] exualized representations of women and animals often drew on stereotypical feminine characteristics, heterosexual love affairs, and patriarchal versions of romance" (Kalof, Fitzgerald and Baralt 2004: 242). Even contemporary literature in environmental ethics relies on this linkage. Ecofeminist philosopher Victoria Davion critiques well-known environmental philosopher Holmes 
Rolston for linking hunting with a natural expression of the sex drive (Davion 2007: 171). Understanding the history of American sports hunting and its linkage to power, especially via patriarchy and colonialism, is key for understanding the success of the Cecil narrative. I dedicate more to this discussion in the next section, but here it is worth continuing to examine how the media relies on the connection between sex and violence.

The media's sexualization of stories involving wild animals is not unprecedented. Western culture is thoroughly suffused with intersecting and mutually reinforcing dualisms of gender, race, and animality. Ecofeminist philosopher Val Plumwood writes about the media's transformation of her story of surviving a saltwater crocodile attack during fieldwork in Northwestern Australia into a tale of a "sadistic rape." Though in her case the symbols are transposed: she was the victim while the croc was the masculinized perpetrator. This transposition reinforces gendered power relations: it implies "the bush is no place for a woman" and that those women who transgress this warning will suffer repercussions (Plumwood 1995). I discuss Plumwood's interpretation of her account in more detail below. Here it's worth noting how metaphors of sexual violence are reliably invoked to tell stories about encounters with wild animals even if the symbols are fluid. The common denominator, we shall see, is how they channel sympathy to reinforce power along lines of gender and race.

Sympathy garnered through the narratives surrounding Cecil's death cannot be understood apart from the western gender norms that are attached to hunting. In the next section, I look at the development of sports hunting as a way of preserving and performing white masculinity. What becomes clear is that Palmer was not chastised merely for trophy hunting, but for his perceived violation of certain hunting norms attached to the performance of masculinity and power. This analysis reveals, in turn, the way in which non-human animals help define the boundaries of humanity, gender, and race. Which types of people and animals are deserving of sympathy? Who belongs in the moral community?

\section{Hunting, gender, and power}

There is a discernable history in the United States of the intentional linkages of masculinity and sports hunting. Likewise, hunting has historically been a display of power and colonialism in the United States and beyond. These norms guide proper and improper ways to hunt: who can hunt, where, when, and why. While many organizations are explicit about these rules, they probably operate only in the background of popular attitudes toward hunting. ${ }^{10}$ In this section, I draw from ecofeminism, animal studies, and political ecology to make clear how these background assumptions help direct sympathy for environmental issues. Sports hunting in the western mind is laden with gendered assumptions about both the hunter and nature. These attitudes reveal how the western imaginary relies upon a gendered nature to define the boundaries of humanity, masculinity, and whiteness.

Ecofeminist Marti Kheel offers an interesting analysis of the complex origins of sports hunting in the United States toward the end of the nineteenth century. It evolved as part of a strategy for preserving white masculinity, which at the time was thought to be under threat. In this period, gender roles had shifted rapidly with the changes brought by urbanization and industrialization. Kheel discusses the rise of what she calls the "Masculine Primitive" man, which developed alongside the compassionate, disciplined "Christian Gentleman" and the self-made "Masculine Achiever" (Kheel 2008: 85). The notion of the Masculine Primitive was both challenged and amplified by Darwin's work. If man was merely an animal, then "at least he could express his 'animal' impulses in a rationally controlled and regulated manner" (Kheel 2008: 85). Hunting was seen as the paradigmatic activity for expressing this type of masculinity in such a manner - one that distinguished upper class, American men from poor southern whites, immigrants, and blacks, as well as from the rest of nature (Kheel 2008: 78-79). U.S. President Theodore Roosevelt was perhaps one of the most visible figures promoting these new ideals within American culture.

While on an unsuccessful big-game hunting trip in Louisiana in 1902, U.S. President Roosevelt's guides became worried about his returning empty-handed, so they tied up an American black bear for him to find and kill. However, the president refused to shoot the tethered bear. This act was memorized in the rise of the teddy bear toy ("The Real Teddy Bear Story" n.d.), popular almost immediately. In sparing the bear, Roosevelt was

\footnotetext{
${ }^{10}$ For instance, see the Boone and Crocket Club's (n.d.) "Fair Chase Statement."
} 
demonstrating this new way of hunting as an expression of manliness, one that incorporates self-restraint into sportsmanship (Kheel 2008: 70 and 97n5). Importantly, the Cecil narrative suggests that Palmer failed at this performance. Although across time and culture, strict norms have defined the who, what, how, why, and when of hunting, hunting as a sport in America became a unique way of expressing, and rescuing, a version of masculinity. A number of newly created sports clubs, societies, and journals helped define the rules of this sport although they were quite simple: the hunt must exhibit both mastery of the beast within and without; one hunted for the sport of it and never as a means of subsistence (Kheel 2008: 78-79). Sports hunting was marked as a way of demonstrating class and racial hierarchy, and had traditionally been contrasted with subsistence hunting, which was seen as "haphazard, inefficient, wasteful, and cruel", especially in colonized African territories (W. M. Adams 2004: 31), where Roosevelt spent an entire year on safari. ${ }^{11}$ While nature is regulated by inviolable laws, "man" is free and able to transcend his nature: his instinct, appetite, and baser desires. A "true man" demonstrates his masculine virtues by pulling the trigger only at the right time to take the right game. The bigger and more dangerous, the better. ${ }^{12}$ Outside the feminizing influences of the city, and away from law and society, men were able to demonstrate their ability to obey the rules of the hunt. And demonstrating mastery over only one kind of animal was not enough. To become a member of Roosevelt's Boone and Crockett Club, one had to kill three types of America's "big game" with a rifle (Kheel 2008: 79). The Boy Scouts, along with many childhood educators, also promoted hunting and encounters with wilderness as appropriate forms of instruction for young boys (Kheel 2008: 87). As more men left farms for work in the city and more women became teachers, young boys faced a perceived threat of "over-feminization" and needed a new manner of instruction which these new organizations provided (Kheel 2008: 70, 84).

The new "sportsman" approach to hunting for which Roosevelt advocated was markedly different from its predecessors for several reasons:

The significance of the change was not merely that moral rules were now attached to the conduct of hunting, but rather that hunting was, for the first time, conceived as an essential activity for the conservation of the country's natural resources, and simultaneously as a morally beneficial activity, especially for men. (Kheel 2008: 71)

These new hunters were often part of the early conservation movement in the United States and crucial to its success. They sought to protect game populations for hunters. Interestingly, North American predators such as coyotes and wolves were not protected since they were "competitors who robbed sportsmen of the opportunities to hunt" (Kheel 2008: 78). ${ }^{13}$ The early sportsman-conservationist was more concerned with the influence of commercial hunting, as well as the "pothunting" immigrants, blacks, and poor southern whites. These groups, it was argued, hunted merely for food or for profit. They paid no mind to preserving game or the land required to sustain it (Kheel 2008: 78). In one sense, then, sports hunting became another form of primitive accumulation, or appropriation of the commons (Curtin 2005: 43). It sought to establish stricter limits on who should have

\footnotetext{
11 "In the early part of the twentieth century hunting expeditions by high-profile 'celebrities' of their day, such as Theodore Roosevelt, served to bring the idea of the safari to international attention. Roosevelt's tour of Africa in 1908 was indicative of a new wave of safari hunters, with the result that by the end of the First World War safaris had become a specialized international business" (Duffy 2010: 84). This attention helped jump-start the safari business, which today brings in over US\$341 million to the South African economy alone (Saayman, van der Merwe and Saayman 2018).

12 The website of the Boone and Crockett Club (n.d.) has detailed rules for scoring trophies. These rules are based on skull, horn, or tusk size depending on the animal. Record-keeping encourages competition among members of hunting fraternities. However, size is not always an indication of the threat an animal poses: "A mature lion with a huge skull succumbs to highvelocity bullets with the same limb-entangled tumble as a subadult whose trophy measurements will never find its way into a record book;" rather, trophy size displays wealth since hunting increasingly rare large game and then transporting, processing, and scoring larger carcasses costs more (Loveridge 2018: 213).

${ }^{13}$ There is a noticeable dearth of information on the financial impacts of livestock predation in North America and Europe when compared to post-colonial countries (Thirgood, Woodroffe and Rabinowitz 2005: 17-18). Some numbers suggest farmers are compensated more for cattle and sheep lost due to predation in the United States vs. in Laikipia (Frank, Woodroffe, Rosie, and Ogada 2005: 302-3).
} 
access to the resources of hunting. The sport was reserved for the wealthy elite who practiced it in part to display their status, their mastery over both their baser needs and their social inferiors. Hunting in this sense becomes an "expression of power which the ruling race or species exerts over the powerless" (Spiegel 1996: 64) - both animals and those denied access to them in the name of "conservation." Crucial then was the distance between pothunting to secure the food necessary for sustaining life, and sports hunting which demonstrated the elite hunter's transcendence of that necessity. Even Tarzan of the jungle could kill for pleasure instead of just food, an indication of his civilized nature (Curtin 2005: 30). This logic was replicated in colonial Africa where many wealthy hunters would travel to practice their sport as big game became rarer at home. Only white colonizers were trusted with the privilege of hunting. Africans who hunted for food were regarded as destructive, wasteful, and cruel in their choice of primitive weaponry, while Europeans were able to act as guardians of wildlife, precise with their high-tech firearms and pure in their virtuous motives (Somerville 2020: 78).

Whiteness and masculinity - what they are and what they are not - are both defined in part by presumptions about nature, (non-human) animality, and hunting. Plumwood offers an analysis of how this system of mutually reinforcing dualisms works. She draws upon her experience of surviving the crocodile attack to reflect on what she elsewhere calls the "master narrative", a "logic of colonialism" that uses a series of intersectional dualisms through which the master identity appropriates subordinated identities into its own, thereby defining itself in part by negation: the masculine is defined as opposed to feminine, the human is opposed to animal, reason is opposed to passion, etc. (Plumwood 1993). Those identities on the master side draw from each other to devalue the subordinated side of the dualism. This forms what Plumwood calls an interlocking structure or system of identity (Plumwood 1993: 43). In other words, to be male is associated with being the epitome of a rational human, while to be female is to be emotional and lesser. Like Adams' absent referent which operates by relying on an excluded reference, the master identity relies on a "denied dependency on the subordinated other" (Plumwood 1993: 41). She details how this system of binaries runs throughout western culture (from as early as Plato). Western media outlets reproduce these familiar tropes since they are easy for popular audiences to digest. Importantly they often operate subconsciously and can migrate and shift meanings to reinforce power relations between master and subordinated identities. The croc is masculinized to keep women "in their place" while Cecil becomes a helpless victim of misperformed masculinity to rebuke an otherwise ordinary instance of trophy hunting - a practice that has been proven to protect lions and provide benefits to communities who live near them.

Public discourse about the ethical treatment of non-human animals often disguises underlying conflicts about culture and race; for instance, public debates over whether practices such as whale-hunting or dog fighting are seen as culturally significant or barbaric are heavily saturated with assumptions about the conceptual entwinement of race and animality (Kim 2015). Thus, these discussions provide important insights into how the white imaginary understands whiteness alongside non-human animals and people of color. For instance, take the death of Harambe in 2016. Kim (2017) notes that the controversy which surrounded the event cannot be understood without looking at the intersectional role of race and animality. Both the boy who fell into Harambe's gorilla enclosure and his parents were black. ${ }^{14}$ When zookeepers shot Harambe to protect the boy, the outpouring of sympathy was primarily directed at the gorilla, accompanied by anger at both the zoo and the boy's parents. ${ }^{15}$ Drawing from animal studies, literature, film, and the field notes of eighteenth-century naturalist-explorers Kim illustrates the connection between animality and blackness as they are invoked to help reinforce what it means to be human and white (Kim 2017). Yet these boundaries are fluid and mobile too. Although gorillas have been associated with the bestial, blackness, and the unpredictably violent in scientific and popular imaginaries, Kim concludes that Harambe's death was only grieveable "because there was someone black(er) [i.e., a black child] on the scene" (Kim 2017: 7). Were the parents white, it's likely that the court of public opinion, and perhaps actual courts, would have deemed the zoo culpable for risking serious harm or

\footnotetext{
14 Although his father wasn't present, this was seen as further proof of the black family's fault. Stories even reveal the boy's father had a "criminal history" playing simultaneously on the tropes of black criminality and absentee parenting (Kim 2017: 7).

${ }^{15}$ Note a significant threat to wild lion populations comes from people intentionally killing lions who have proved to be a threat to humans or their livestock.
} 
death to visiting children (Kim 2017: 7). Adams, Plumwood, and Kim all help reveal that to understand when the otherwise unremarkable death of a non-human animal deserves sympathy and calls for moral indignation, we must look at when and where other norms are violated. It remains an open question whether sympathy for non-humans can operate without a problematic othering.

Indeed, the contrast between sympathy for gorillas or lions over people is underscored if one considers the contemporaneous reporting on racial politics in the United States. Cecil's death quickly instigated a great deal of sympathy, outrage, and action during a time when the Black Lives Matter movement began highlighting a pattern of extrajudicial police killings affecting people of color. Within 24 hours of identifying Cecil's killer, Palmer's felony records were exposed (Craven and Bellware 2015) and a deluge of protesters and angry Yelpers forced him to shutter his dental practice; the clip of Kimmel went viral and donations to the fund netted over US\$150,000 (Jimmy Kimmel Live 2015b). ${ }^{16}$ Within a week, three major airlines (Delta, American, and Continental) announced that they would no longer transport big game trophies (Cummings 2015). By contrast, it took over six months for a judge to rule that there was probable cause to bring charges against Timothy Loehmann, the police officer who shot and killed Tamir Rice, a 12-year-old black boy who was playing in the park with a toy gun, though a grand jury declined to do so (Lester 2015). Sympathy is disclosive of how one views the moral community and what constitutes a violation against its members. The outpouring of anger over Cecil's suffering, all for a trophy, and the donations and other reactions that followed indicate that those who acted felt sympathy for Cecil; they saw his death as grieveable. ${ }^{17}$

Finally, lions and other non-human animals are often viewed and understood through gendered lenses as well. A male lion, the so-called "king of all beasts", is a symbol of masculinity, power, and dominance; a symbol of the British empire; and a Christ symbol in Christianity. In this light, Palmer's transgression can be read as an emasculation of a powerful symbol of masculinity through unsportsmanlike behavior. Even scientists reporting on Cecil's life used hyper-masculine, aggressive terms. In his book, Lion Hearted, Loveridge (2018) includes a chapter titled "Game of Thrones" (referencing the popular fantasy-novel-turned-TV-series of the same name). In it, he focuses on male lions - their "luxuriant" manes and the number of offspring they sire with whom Cecil had rivalries, rematches, and "unlikely alliances": "Our research has recorded remarkable stories of alliance, collusion, fratricide, tragedy, and conquest that rival the battles and intrigues of the Starks and Lannisters" (both families from Game of Thrones) (Loveridge 2018: 184). In turn, the behavior of female lions in response to new males threatening their cubs is described deploying a number of problematic gender stereotypes:

[Lionesses] will often use all of their feminine guile to bewitch and confuse the new and foolish male...Feigning submission to the new male, a lioness becomes slinky and sinuous, oozing charm and sex appeal, tail curling snakelike across the male's head and shoulders as she entices him to follow her. By mating with him, she distracts him and allows the other lioness to escape with the pride's cubs, including her own. By intoxicating him with feline charm, she wins time for her children. (Loveridge 2018: 36-37)

The lioness is a witch, temptress, and good mother all at once. Meanwhile, a young "dynamite coalition" of males move in to "dethrone" an old male ("live by the sword, die by the sword") (Loveridge 2018: 188). All this is reported while Loveridge marvels at the complex social lives of lions. ${ }^{18}$ While it may be the case that

\footnotetext{
${ }^{16}$ Indeed, Yelp was forced to update its comment policy because of this event. Nearly 4 years after the event, a message still warns people that the business made the news recently, which may affect its rating ("Walter J Palmer, DDS Minneapolis, MN" n.d.).

${ }^{17}$ I don't mean to diminish the organizing and action that followed Rice's death, or the many other police killings that Black Lives Matter has highlighted. It was not for lack of sympathy that Rice's killer walked free. We must also ask how structural forces inhibit or amplify the translation of sympathy into effective change.

${ }^{18}$ I don't mean to suggest anywhere in this article that animals are not capable of complex inner lives. Rather, I want to ask the question, who has the authority to access and represent these inner lives and what broader power relations are reinforced by this presumed access?
} 
understanding male lions and their conflicts is crucial to conserving the animals, it is worth noting that women, along with black and African researchers, are underrepresented authors in publications about lions (Bauer et al. 2019). Access to the complex social dynamics of lions is granted mostly through a male, white, foreign expertise. This gendering is crucial in shaping the western imaginary which has very little access to lions except through the narratives of such experts, reflected in zoos, documentaries, and books for popular audiences.

I have suggested that in order to understand the unprecedented outpouring of sympathy from western donors to what is otherwise an unnoteworthy trophy hunt, the gendered dimensions of the Cecil narrative are important. Palmer's actions are decried (at least publicly) not only as a violation of the moral integrity of the animal, but also of the norms of western, white, hetero masculinity. He emasculated the lion to collect a trophy, a counterfeit token of manhood he didn't properly earn. ${ }^{19}$ Ecofeminism offers this additional layer of analysis for understanding western sympathy. It reveals how sympathy relies upon a problematic dualism of hierarchy and power: the independent masculine subject is defined through contrast with the subordinated, objectified, and feminized other (Plumwood 1993). In the next section, I discuss how the western imaginary operates by subordinating or leaving absent the experiences of people who live in areas that lions inhabit. The legacy of colonialism and its power relations is here a background structure worth considering alongside gender. Together they offer a better understanding of how the Cecil narrative was able to generate so much support.

\section{A political ecology of sympathy}

So far, I have pressed the question, why did Cecil garner so much sympathy? Rejecting WildCRU's answer - anger - as too simple, I examined the background structures that enabled this sympathy. I suggested they rely on a western imaginary suffused with normative assumptions about race, gender, and non-human nature. In this section, I argue that a political ecology of sympathy will help trace these power relations on the ground - how western sympathy affects the people whose lives and livelihood intersect with wildlife management policies of lions and other animals. Political ecology understands environmental conflict as a symptom of wider political struggles rather than as merely ecological. Using political ecology as an analytic framework involves "identifying broader systems rather than blaming proximate and local forces... viewing ecological systems as power-laden rather than politically inert; and... taking an explicitly normative approach rather than one that claims the objectivity of disinterest” (Robbins 2012: 13). The systemic and normative focus on power relations make it easily compatible with an ecofeminist analysis. Environmental conflict today is often part of a wider history of neocolonialism and neoliberalism, though it manifests locally in unique and multifaceted ways. Political ecology is best situated to incorporate local experiences and empirical research in critique of the problematic imaginaries that shape western environmental attitudes. In short, a political ecology of sympathy asks, who benefits from sympathy for Cecil? A question intimately connected to that which I've pressed so far: why Cecil?

First, take a moment to consider why sympathy for a lion's death might be strange. After all, lions are large predators and any human should take care when considering such animals. Lions routinely kill people, perhaps increasingly so in recent decades (Penteriani et al. 2016); however, the numbers are inconsistent. According to one study conducted by the Royal Swedish Academy of Sciences, 552 humans were killed by lions in the $20^{\text {th }}$ century (Löe and Röskaft 2004: 284). ${ }^{20}$ Another study suggests that between 1990 and 2005, 563 Tanzanians alone were killed by lions, with 308 more injured (Packer et al. 2005). "Lions pull people out of bed, attack nursing mothers, and catch children playing outside. Most rural houses have thatched roofs and many have thatched walls, so lions can force their way inside, and toilets are outside" (Packer et al. 2005: 927). Lions are considered pests in many parts of the world. In addition to killing humans they also kill livestock and pose a threat to the livelihood of ranchers. ${ }^{21}$

\footnotetext{
${ }^{19}$ Note that Kimmel also invoked patriotism: "Make a donation... At the very least, maybe we can show the world that not all Americans are like this jackhole [Palmer] here" (Jimmy Kimmel Live 2015a). As noted above, the connection between conservation and nation is another important theme, however I do not have room to explore it more extensively here.

${ }^{20}$ The authors suggest this is an under-estimation due to poor record keeping.

21 The Dutch began introducing game laws in the Cape in 1657, and within several decades they classified lions as vermin while protecting other animals (W.M. Adams 2004: 22).
} 
In a New York Times op-ed, Zimbabwean-born Goodwill Nzo (2015), a then-doctoral student at Wake Forest University, reflected on the response to Cecil's death, calling it "the starkest cultural contradiction I'd experienced during my five years studying in the United States." He recounts how his home has been "terrorized" by lions, how his uncle lost a leg in a lion attack, and how a 14-year-old neighbor was killed by a lion while sleeping in the fields to prevent hippos, buffalo, and elephants (all large animals that routinely kill humans) from trampling crops. His observations echo those of Kim's (2017) concerning sympathy, race and the reaction to Harambe's death: "We Zimbabweans", he writes, "are left shaking our heads, wondering why Americans care more about African animals than about African people." He goes on: "please, don't offer me condolences about Cecil unless you're also willing to offer me condolences for villagers killed or left hungry by his brethren, by political violence, or by hunger" (Nzo 2015). Many within Zimbabwe heard of both Cecil and his death only through stories run in western media outlets. Local reports shared Nzo's concerns about western focus on lions over people (Somerville 2017). Even still, Nzo represents but one of many complicated attitudes toward lions held by Zimbabweans. For instance, some stand to benefit economically from the presence of lions while others view them as pests which threaten lives or livelihood. Sympathy is disclosive of these divides between those who think protecting lions is worth the cost and those who do not.

A complicated history of this divide exists in both Zimbabwe and other formerly colonized African countries where lions and big game are present. Empires quickly realized the potential for big game to attract wealthy hunters. They understood conservation as a lucrative investment, which by the early 1900s amounted to over $£ 30,000$ annually in British East Africa (W.M. Adams 2004: 38). This justified displacement of people in the name of a conservation bent on protecting the investments of empire. Conserving healthy populations of big game, especially lions, requires a large territory with a healthy prey game population for the lions to eat. History shows that protecting these large spaces for wildlife often comes at the cost of violent displacement of poor or indigenous people. In many cases, there is an ongoing violence of criminalizing the use of resources, granting the elite access to them while denying such access to the poor; for instance, consider the transformation of hunting bushmeat as a longstanding practice into illegal poaching (Duffy 2010). When conflicts arise, ignoring these histories facilitates sympathy with wildlife over people; for instance, when all poachers are portrayed as money hungry ivory hunters, rather than as impoverished and hungry hunters, it's far easier to sympathize with the non-human animals.

Although displacement of people worldwide to create, preserve, or simulate the western wilderness aesthetic is well documented by environmental historians (Spence 1999) and political ecologists (Dowie 2009; Duffy 2010; West, Igoe and Brockington 2006), few sympathetic westerners realize how this form of violence shapes the imaginary through which they understand environmental conflict. Importantly, this imaginary is not devoid of people by accident. There is a long history of erasing the presence of indigenous people living within or alongside nature parks to "preserve" said spaces (Cronon 1995; Guha 1989). ${ }^{22}$ Ansel Adams, photographer of the American West, including Yosemite Valley, was an early architect of the American wilderness imaginary, which he helped portray as unpopulated. He meticulously worked to not merely marginalize, but exclude entirely, evidence of the Miwok people who had inhabited the valley for 4,000 years before being forcibly removed (Dowie 2009: 16; Spence 1999: 115-132). In some instances, this evidence was just outside the frame of his iconic photos. Such practices continued in modern day nature documentaries through which many westerners encounter animals such as lions. The BBC program Big Cat Diary intentionally avoided discussing human-wildlife conflict because it was deemed too depressing for western audiences (Somerville 2020: 134). Nature documentaries provide westerners an optics of animals in carefully framed wilderness environments blissfully devoid of people, suggesting that when conflicts do arise, it's the fault of people intruding on wilderness and never vice versa. Suggesting that people are responsible for the demise of lions, for instance, helps perpetuate the colonial-era idea that African people are not capable of managing African wildlife (Duffy 2001: 1). The task of protecting wildlife falls instead on appropriately sympathetic westerners and the disinterested sciences of Oxford elites.

With independence, many African countries inherited a system of conservation and wildlife management that was designed by, and for the benefit of, colonial powers (Somerville 2020: 117). In Zimbabwe, these

\footnotetext{
${ }^{22}$ For more on how American wilderness is imagined and shaped as white space, see Finney (2014).
} 
powers were simply transferred over to elite groups well-connected to former white settlers (Scoones 2015). In 1975, the Parks and Wildlife Act gave mostly white landowners rights to the game on their property, which allowed them to establish profitable hunting outfits, an industry then worth Z\$10 million (Somerville 2020: 202). Black subsistence farmers were relocated to communal lands which restricted hunting and other activities, directing most benefits from wildlife into the pockets of white elites (Somerville 2020: 202). This began to change with the introduction of CAMPFIRE (Communal Areas Management Program for Indigenous Resources) in 1988, which operated in partnership with rural communities to benefit both people and wildlife. From then until the early 2000s, Zimbabwe had been a model for conservation and sustainable hunting led by local community groups (Vira and Ewing 2014: 49). Up to 90\% of the revenue collected went back to local communities (Scoones 2015). The income of some communities studied increased by about 75\% between 198995, $90 \%$ of which came from sports hunting, with lions being the most popular animals hunted (Somerville 2020: 202). ${ }^{23}$

But old habits die hard. Much changed at the turn of the century in part because of political fallout from Zimbabwe President Mugabe's post-colonial land reformation - transferring land from former white settlers to black citizens. Both the land reform and international responses to it impaired CAMPFIRE's ability to protect animals while benefiting the broader community. In 2003, U.S. President Bush issued economic sanctions that prohibited Americans from doing business with Mugabe or many of his top officials citing the "antidemocratic" nature of Zimbabwe's land redistribution policies. These sanctions were introduced over the protests of many African leaders who recognized redistribution as an appropriate form of restorative justice (Stout 2003). ${ }^{24}$

Mugabe's land reformation was controversial for many other reasons though. First, the income lost as the result of United States-led sanctions encouraged an increase in land seizures by Mugabe and his party associates. While the land reform was promoted as a means of reducing inequality by providing poorer Zimbabweans with land, those with ties to Mugabe's family and close political allies control about $40 \%$ of those lands seized from farms and conservancies (Vira and Ewing 2014: 50). For instance, Ndlovu, the owner of the farm on which Cecil was shot, is counted as one such well-connected beneficiary of Mugabe's land policy (Scoones 2015). Those outside of the privileged circle were often relocated to less productive lands, making alternative sources of income - e.g., allowing hunting/poaching - more attractive. Meanwhile, connected elites do not fear sanctions from violating hunting laws, as Ndlovu's actions demonstrate. Land use management is crucial both to understanding Zimbabwe's political history (Duffy 2001: 10), and, importantly, to conserving healthy lion populations. Second, the increasing need for the government to secure more funding continued the trend, started in the 1990s, of confiscating the control that local park systems had over their own revenue and resources (Duffy 2001: 26). This was a far-from-insignificant sum of money since tourism, much of which is generated by interest in the parks, is one of the most important sources of revenue for Zimbabwe. ${ }^{25}$ Finally, it seriously upset the country's agricultural industry, leading to an increasing need to turn to bushmeat to stave off starvation (Vira and Ewing 2014: 50). This in turn put pressure on predators who would otherwise eat such animals, thereby increasing human-lion conflict. Lions became more likely to attack livestock herds on nearby farms. Poor, small-scale farmers make up most of the people who live alongside nature preserves. Conservation denies them access to resources such as bushmeat in the interest of preserving the tourist money brought in by big game. At the same time, they and their livestock are subjected to the increased threat of lion attacks. They are less capable of affording the protective barriers to stave off such attacks (Somerville 2020: 176). The financial burden posed by lions is far from insignificant. For instance, lion predation on livestock herds caused nearly a 20\% drop in annual income in communities studied in Tanzania (Somerville 2020: 146). ${ }^{26}$

In other words, the elite once again monopolize the right to benefit from lions, while distancing themselves from the cost and risks that such animals bring. International sanctions, the collapse of agriculture,

\footnotetext{
${ }^{23}$ Though this and programs like it are not without their problems (Duffy 2001: 89-112; Duffy 2010: 97-99; Somerville 2020: 202).

${ }^{24}$ Zimbabwe reached black majority rule for the first time since its independence in 1980, the year Mugabe took power (Stout 2003).

${ }^{25}$ In the 1990s, Hwange National Park was bringing in Z\$4 million each year (Duffy 2001: 26).

${ }^{26}$ For contrast with predation loss for American farmers, see note 13 above.
} 
and mismanagement of wildlife by newly relocated landowners have all helped increase pressures on lion and other wildlife populations. Politics and history, which are largely ignored when appeals are made to western sympathy, complicate the simple and widely disseminated western belief that careless and selfish people endanger animals. Rather, lions and other wildlife do best when local communities benefit rather than suffer from their presence (Somerville 2020: 186). The uncomfortable fact that WildCRU knows, and which sympathetic westerners may avoid, is that many carefully regulated trophy hunting policies have helped communities.

\section{Conclusion: neither lions nor people}

The upshot is that western sympathy does not necessarily protect either lions from trophy hunts, or the vulnerable people who depend upon them from disruptions to their lives or livelihood. The unprecedented outpouring of western sympathy, expressed in financial donations, encouraged Zimbabwe to put an immediate, though temporary (9-day), suspension of hunting in the Hwange region (Somerville 2017: 482). However, the effects of this suspension, and the subsequent discussions of western powers to ban trophy hunting imports, rippled beyond Hwange through communities that rely upon the industry for income (Somerville 2020: 204). Evidence suggests that "if you take away hunting income when there is no alternative then you reduce funding available for conservation while impoverishing further and creating greater grievances among people who have to coexist with lions" (Somerville 2020: 209). Studies show other forms of tourism are not nearly as lucrative as hunting tourism, and, in some regions, the revenue it generates is less likely to be redistributed locally than money generated by hunting (Somerville 2020: 210). Donors moved by Kimmel's tears as he begged viewers to give to WildCRU in order "to have some good come out of this disgusting tragedy" (Jimmy Kimmel Live 2015a) probably expected their money would go to help prevent trophy hunting. The truth is WildCRU is not publicly opposed to trophy hunting (WildCRU 2019). In a report prepared for the U.K. Secretary of State for the Environment, they note that well-managed trophy hunting programs help increase lion populations (MacDonald 2016). Between 1993 and 2014, Namibia and Zimbabwe were the only two African countries that substantially increased their lion populations, and both permit trophy hunting (MacDonald 2016: 2). The report ultimately recommends that British and other governments should allow the import of lion trophies when "the hunting (a) was unlikely to cause detriment to the lion population from which it was taken, and (b) contributes to lion conservation" (MacDonald 2016: 70).

This disparity between donors' concerns and policy highlights the problem with relying on the narrative provided by WildCRU or other environmental elites: conservation groups are powerful entities, capable of mobilizing a great deal of public financial support across the world with little accountability to national or local governments (Duffy 2010: 64). Donors were staunchly against trophy hunting according to WildCRU's own studies, and yet many donated anyway. According to WildCRU, the purpose of their study is both lion conservation and "advancing the well-being of human communities living alongside them" (Macdonald and Jacobsen et al. 2016: 2). While evidence clearly indicates the connection between trophy hunting and local livelihood, WildCRU still has the influence to define the terms under which western powers will support or impede the hunting industry. At the same time, wildlife conservation groups are themselves under pressure from an international, multibillion-dollar hunting industry. Loveridge recounts how research permits are quickly revoked from those who push too hard against the monied interests of industry or political officials (Loveridge 2018: 106-107). In any case, conservation groups benefit from the western imaginary and all its misconceptions. Post Cecil, WildCRU spent a lot of effort attempting to understand how the sudden public interest could be sustained, asking what it would take to "transform the Cecil Moment into the Cecil Movement" (MacDonald 2016: xiii; MacDonald and Jacobsen et al. 2016: 10).

Lion conservation is no easy task. There are many competing interests and the practice raises serious ethical questions not considered here. A political ecology of sympathy can closely track the beneficiaries of the unprecedented support that Cecil raised. Donors were moved by white, western, male tears when they learned of a perfectly ordinary trophy hunt portrayed as something much more unusual and sinister. Yet there was nothing unusual about Cecil's death - neither with how he was killed nor why. The only thing that was illegal about his death was some missing paperwork - a permit to hunt on Ndlovu's property. Those permits are meant 
to protect the health and integrity of lions as a species, but they are also meant to control who can profit from lions as a resource. These policies sometimes do not account for the costs borne by those coexisting with lions. The narratives that succeeded in having the most resonance with western culture were those that evoked (at times more or less subtly) norms at the intersection of gender, race, animality, and hunting. At the same time, these narratives remained mostly ignorant of the colonial histories and current political struggles of those who coexist with lions. Ecofeminism offers theoretical insight into the western imaginary that activates western sympathy to power global conservation. Political ecology can help trace who has interests in maintaining those power relations while identifying their effects on local people.

Elites have always used their power to designate wildlife a resource that they alone have a right to exploit, a right often grounded in their presumed moral integrity to exploit sustainably. While this is true of the current situation in Zimbabwe, the same attitude is also reflected in the collective turn to the Oxford elites. Once again, western sympathy for Zimbabwean wildlife is presumed to be in the interest of the "global environmental good" (Duffy 2001: 1). In this sense, the history of western-style conservation is linked to colonialism. Mitchell (2017) notes that "Western children are more likely to recognize megafauna from other continents than plants endemic to the lands where they live." Americans who are often unaware of how many species are under threat of extinction in their own territories, let alone the immense costs associated with protecting them (Kahn 2018), will donate to save species in other parts of the world, all while blissfully unaware of their own contribution to the major drivers of extinction rooted in global capitalism (Dawson 2016). Sympathy for Cecil signals that lions are under the ward of the west. They are off limits unless the price is right. Misguided sympathy, translated into funding for international NGOs, can adversely affect the lives of the people who live near lion preserves. Western donors are not mobilized by anger alone. Background assumptions and environmental imaginaries activate and amplify that anger. I have suggested how gender, race, and colonialism influence this imaginary to facilitate anger. I am not suggesting that hunting lions for trophy is morally permissible - that Cecil's death was not reprehensible - nor am I suggesting that all those who live near lion territories will feel the same way about trophy hunting. Finally, I am also not suggesting that WildCRU has been intentionally disingenuous in their mission, or that their policies have not increased lion populations while benefiting people. Rather, my aim here has been to trace out the power relations disclosed by an examination of the sympathy expressed for Cecil. An analysis drawing from ecofeminism and political ecology of sympathy can help demarcate the wider justice implications of this well-intentioned response and help to realign it.

\section{References}

Adams, C.J. 2000. The sexual politics of meat: a feminist-vegetarian critical theory. New York: Continuum.

Adams, W.M. 2004. Against extinction: the story of conservation. London: Earthscan.

Bauer, H., F. Gebresenbet, M. Kiki, L. Simpson, and C. Sillero-Zubiri. 2019. Race and gender bias in the research community on African lions. Frontiers in Ecology and Evolution 7(24): 1-4.

Boone and Crockett Club (n.d.). Website. https://www.boone-crockett.org. [accessed May 23, 2018]

Cooper, D.E. 2015. Animals, attitudes and moral theories. In Kidd, I.J. and L. McKinnell (eds.). Science and the self: animals, evolution, and ethics: essays in honour of Mary Midgley. New York: Routledge. Pp. 19-30.

Craven, J. and K. Bellware. 2015. We weep for African lions. But what about black lives? HuffPost, July 30. [accessed June 27, 2019]

Cronon, W. 1995. The trouble with wilderness; or, getting back to the wrong nature. In Cronon, W. (ed.). Uncommon ground: rethinking the human place in nature. New York: Norton \& Co. Pp. 69-90.

Cummings, W. 2015. Airlines ban hunters' big-game 'trophies' after uproar over Cecil the Lion. USA Today, August 3. [accessed June 27, 2019]

Curtin, D. 2005. Environmental ethics for a postcolonial world. Lanham, MD: Rowman \& Littlefield.

Davion, V. 2007. Caring for nature: an ecofeminist's view of Rolston on eating, hunting, and genetics. In Preston, C.J. and W. Ouderkirk (eds.). Nature, value, duty: life on earth with Holmes Rolston, III. Dordrecht: Springer. Pp. 167-181. excerpt 
Dawson, A. 2016. Extinction: a radical history. New York: OR Books.

Dowie, M. 2009. Conservation refugees: the hundred-year conflict between global conservation and native peoples. Cambridge, MA: MIT Press.

Duffy, R. 2001. Killing for conservation: wildlife policy in Zimbabwe. Bloomington, IN: Indiana University Press.

Duffy, R. 2010. Nature crime: how we're getting conservation wrong. New Haven, CT: Yale University Press.

Finney. C. 2014. Black faces, white spaces: reimagining the relationship of African Americans to the great outdoors. Chapel Hill: University of North Carolina Press.

Frank, L.G., R. Woodroffe and M. Ogada. 2005. People and predators in Laikipia District, Kenya. In Woodroffe, R., S. Thirgood, and A. Rabinowitz (eds.). People and wildlife: conflict or coexistence? Cambridge: Cambridge University Press. Pp. 286-304.

Guha, R. 1989. Radical American environmentalism and wilderness preservation: a third world critique. Environmental Ethics 11(1): 71-83.

Hatkoff, C., J. Hatkoff and I. Hatkoff. 2016. Cecil's pride: the true story of a lion king. New York: Scholastic Press.

Jenkins, N. 2015. Who is really responsible for the killing of Zim's wildlife? The Standard, August 3. [accessed June 27, 2019]

Jimmy Kimmel Live. 2015a. Television broadcast. Episode 98, July 28. American Broadcast Company.

Jimmy Kimmel Live. 2015b. Jimmy Kimmel helps raise \$150,000 after Cecil the Lion monologue. ABC. July 30. [accessed July 23, 2019]

Kahn, J. 2018. Should some species be allowed to die out? New York Times, March 13. https://www.nytimes.com/2018/03/13/magazine/should-some-species-be-allowed-to-die-out.html. [accessed July 9, 2019]

Kalof, L., A. Fitzgerald and L. Baralt. 2004. Animals, women, and weapons: blurred sexual boundaries in the discourse of sport hunting. Society and Animals 12(3): 237-251.

Kheel, M. 2008. Nature ethics: an ecofeminist perspective. Lanham, MD: Rowman \& Littlefield.

Kim, C.J. 2017. Murder and mattering in Harambe's house. Politics and Animals 3: 1-15.

Kim, C.J. Dangerous crossings: race, species, and nature in a multicultural age. Cambridge: Cambridge University Press.

Kings, A.E. 2017. Intersectionality and the changing face of ecofeminism. Ethics and the Environment 22(1): 63-87.

Lester, M. 2015. Timeline of Tamir Rice case. New York Times, December 28. https://www.nytimes.com/2015/12/29/us/tamir-rice-police-shootiing-cleveland.html [accessed July 23, 2019]

Löe, J., and E. Röskaft. 2004. Large carnivores and human safety: a review. AMBIO: A Journal of the Human Environment 33(6): 283-288.

Loveridge, A. 2018. Lion hearted: the life and death of Cecil and the future of Africa's iconic cats. New York, NY: Regan Arts.

Macdonald, D.W. 2016. Report on lion conservation with particular respect to the issue of trophy hunting. Report. Oxford: WildCRU.

Macdonald, D.W., K.S. Jacobsen, D. Burnham, P.J. Johnson and A.J. Loveridge. 2016. Cecil: a moment or a movement? Analysis of media coverage of the death of a lion, panthera leo. Animals 6(5): 26.

Macdonald, D.W., P.J. Johnson, A.J. Loveridge, D. Burnham and A.J. Dickman. 2016. Conservation or the moral high ground: siding with Bentham or Kant. Conservation Letters 9(4): 307-8.

Mallory, C. 2018. What's in a name? In defense of ecofeminism (not ecological feminisms, feminist ecology, or gender and the environment): or 'why ecofeminism need not be ecofeminine-but so what if it is?' Ethics and the Environment 23(2): 11-35. 
Mellor, M. 1998. Feminism and ecology: an introduction. New York: NYU Press.

Miller, M.E. 2015. Zimbabwe charges farmer over killing of Cecil the Lion, but not American dentist. Washington Post, August 19. https://www.washingtonpost.com/news/morningmix/wp/2015/08/19/zimbabwe-charges-farmer-over-killing-of-cecil-the-lion-but-not-american-dentist [accessed July 1, 2019]

Mitchell, A. 2017. Decolonizing against extinction, part III: white tears and mourning. Worldly (blog), December 14. [accessed April 20, 2020]

Nzo, G. 2015. In Zimbabwe, we don't cry for lions. New York Times, August 5. https://www.nytimes.com/2015/08/05/opinion/in-zimbabwe-we-dont-cry-for-lions.html [accessed July 9, 2019]

Packer, C., D. Ikanda, B. Kissui, and H. Kushnir. 2005. Lion attacks on humans in Tanzania. Nature 436 (7053): 927-928.

Pearce, M. 2018. It took 13 years, two trials and an army of accusers to convict Bill Cosby of one sexual assault. LA Times, September 25. https://www.latimes.com/nation/la-na-cosby-army-20180925-story.html [accessed July 3, 2019]

Penteriani, V., M. del Mar Delgado, F. Pinchera, J. Naves, A. Fernández-Gil, I. Kojola, S. Härkönen, et al. 2016. Human behaviour can trigger large carnivore attacks in developed countries. Scientific Reports 6 (February).

Plumwood, V. 1993. Feminism and the mastery of nature. London: Routledge.

Plumwood, V. 1995. Human vulnerability and the experience of being prey. Quadrant 39(3): 29-34.

Robbins P. 2012. Political ecology: a critical introduction. $2^{\text {nd }}$ ed. Oxford: Wiley-Blackwell.

Saayman, M., P. van der Merwe and A. Saayman. 2018. The economic impact of trophy hunting in the South African wildlife industry. Global Ecology and Conservation 16 (October): 1-9.

Scoones, I. 2015. Why Cecil the lion offers lessons for land reform and the role of elites. The Conversation, August 5. [accessed April 30, 2020]

Somerville, K. 2020. Humans and lions: conflict, conservation, and coexistence. London: Routledge.

Somerville, K. 2017. Cecil the lion in the British media: the pride and prejudice of the press. Journal of African Media Studies 9(3): 471-485.

Spence, M.D. 1999. Dispossessing the wilderness: Indian removal and the making of the national parks. Oxford: Oxford University Press.

Spiegel, M. 1996. The dreaded comparison: human and animal slavery. New York: Mirror Books.

Stout, D. 2003. Bush orders sanctions imposed against leaders of Zimbabwe. New York Times, March 8. https://www.nytimes.com/2003/03/08/world/bush-orders-sanctions-imposed-against-leaders-ofzimbabwe.html [accessed July 11, 2019]

The real Teddy Bear story. n.d. Theodore Roosevelt Association. Website. [accessed June 27, 2019]

Thirgood, S., R. Woodroffe and A. Rabinowitz. 2005. The impact of human-wildlife conflict on human lives and livelihoods. In Woodroffe, R., S. Thirgood and A. Rabinowitz. People and wildlife: conflict or coexistence? Cambridge: Cambridge University Press. Pp. 13-26.

Vira, V. and T. Ewing. 2014. Ivory's curse: the militarization and professionalization of poaching in Africa. C4ADS and Born Free USA.

Walter J Palmer, DDS - Minneapolis, MN. n.d. Yelp. Website. [accessed June 29, 2019]

West, P., J. Igoe and D. Brockington. 2006. Parks and peoples: the social impact of protected areas. Annual Review of Anthropology 35(1): 251-277.

WildCRU. 2019. WildCRU statement about trophy hunting debate. Oxford: Wildlife Conservation Research Unit. [accessed June 18, 2020]

WildCRU. n.d. Cecil summit. Oxford: Wildlife Conservation Research Unit. [accessed July 11, 2019] 